\title{
レビュー情報を用いた学術本の難易度推定
}

\section{An Estimation of Difficulty for Academic Books using Reviews}

\author{
$\underset{\text { Yuki Nakayama }}{\text { 祐輝 }} \begin{aligned} & \text { 金沢大学大学院自然科学研究科 } \\ & \text { Kanazawa University Graduate School of Natural Science \& Technology }\end{aligned}$ \\ 6174naka@blitz.ec.t.kanazawa-u.ac.jp \\ 南保 英孝 \\ (同上卡) \\ nambodblitz.ec.t.kanazawa-u.ac.jp \\ 木村 春彦 \\ (同上) \\ kimura@blitz.ec.t.kanazawa-u.ac.jp
}

keywords: information retrieval, difficulty, learning support, recommender system

\section{Summary}

A collaborate filtering has been generally used as a method which recommends items to customers. However, recommending academic books, it need to consider difficulty of them and individual amount of knowledge as well as user's preference. If the recommendation method considers only user's preference, they might regret after buying or reading recommended book because it won't match user's appropriate level. In this paper, we focus on academic books and propose a method which estimates the difficulty of academic books using user's reviews. Estimating difficulty of books will support users to search and recommend academic books that match user's skill. Moreover, we evaluated applying our method to academic text books about $\mathrm{C}$ programming Language. We verified that our method is more effective than traditional methods for academic books.

\section{1. は じめに}

ある分野の専門知識を深めたい時に考えられる方法と して，本を読むことや，検索エンジン，e-learning を利 用することなどが挙げられる．しかし, e-learning は情 報量が本や検索エンジンと比べて少ないことや，誰もが e-learning を利用できる学習環境に必ずしも恵まれていな いという欠点がある．また，検索エンジンは短時間で本 よりも膨大な情報を獲得できるという利点があるが , 情 報が多すぎるためにどの情報が一番有用なのかが分から ず，情報の信憑性の問題もある，一方，本は情報量が多 く, かつ信憑性も高く, 詳しい解説が載っているため入 門者から上級者まで柔軟に知識を得ることができる．し かし，レベル・ジャンルが多岐にわたるため，どの本を選 択すれば良いかわからないという問題がある . 特に学術 的な専門書 (以下, 本論文では学術本と呼ぶ)を読むとき にはこの問題か顕著に表れる .この問題に対し , Amazon などでは本を選択する時の指針として，協調フィルタリ ングを用いた推薦システムが広く用いられている.これ は過去の閲覧・購入履歴などの嗜好情報に基づくもので ある．しかしながら，嗜好情報だけで本を選択しても， その本が自分の知識やレベルに合っている本であるとは 限らず，結果として，時間やお金の浪費につながること も考えられる．また，Amazon などでは検索結果を関連
度・人気度・価格などのキーで並び替えることが出来る． しかしながら，学術本を一覧表示させるときには難易度 をキーにすると有用であると考えられる . 難易度で並び 替えることにより, 初学者にとってはスタートとなる本 が見つけやすくなることが期待できる．また，ある本を 十分理解できたユーザーにはより高いレベルの本を選択 するとき，逆に挫折してしまったときには少しレベルの 下がった本を選択するときの指標となる．つまり，学術 本を読む際には，個人の知識量や本の難易度を考慮して 本を選択することが重要である．光こで，本論文では本 の難易度に焦点を絞り，学術本に難易度を付与する手法 を提案する. 光して, 本の難易度を個人の知識量推定の 1 つの指標にできると考え, 知識量推定につなげていく ことを目的としている．以下，第 2 章で関連研究，第 3 章で提案する本の難易度を推定する手法について述べる． 第 4 章では難易度の算出の妥当性を検証した実験・評価 方法について説明し，第 5 章で兴の実験結果および考察 を示す . 最後に , 第 6 章で本論文のまとめとする .

\section{2. 関 連 研 究}

\section{$2 \cdot 1$ レビュー情報を用いた情報推葴と検索}

情報検索および推薦にレビュ一情報を用いる研究はい くつか行われている. [中谷 08] ではマーケティング分野 


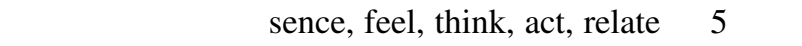
観点からレビューを用いてゲームを分類し，ユーザーの 経験的価值に合ったゲームを推薦している.レビューを 用いて情報を可視化する点では本研究と似ているが, 学 術本では弚の本か理解出来るかが重要なため，5つの観 点から得られる経験的価値は利用できない．学術本にお ける経験的価值とは乥の本が難しかったか, 易しかった かであると考えられる . また本研究では本を対象として いる点も異なっている

[鈴木 09] ではユーザーが好むコンテンツのタイトル からレビューが類似しているコンテンツをユーザーに推 薦している.これは, 本研究と同じく本を扱っているが, 学術本ではなく小説を扱っているという点で異なる．ま た，固定レビューと変動レビューに分類しているが固定 レビューを決めるための固有キーワードを登場人物の名 前や地名としているので学術本に関するレビューには適 用できない .

[倉島 07] では比較評価情報として評価対象，比較対 象，属性，評価を抽出し，対象間の優劣をランキングで 可視化している.対象を映画としており，評価として「良 い」「優れている」という比較の方法をしている.本研究 では優劣ではなく難易度で比較しようとしている点で異 なる .

[杉木 08]では自然言語で記述された検索クエリに適応 する商品検索手法を提案している.学術本であれば「ユー ザーのレベルに合った本」などと検索できればよいが, 自 然文のクェリ以外に個人の知識量も考慮して検索する必 要があるため，この手法では難しいと思われる .

\section{$2 \cdot 2$ テキスト情報を用いた難易度推定}

テキストから対象の難易度を推定する研究はいくつか 行われている . [Nishihara 05] では各 Web ページの特徵 語 (入カキーワードの説明に用いられている単語) を抽出 し, 特徵語の難しさの評価値の和から Web ページの難易 度を算出している . 特徵語の難しさとして出現頻度が低 いほど，難しく意味を捉えにくいと考え，特徵語の出現 頻度を用いている . [Nishihara 05] は被験者に付けても らった Web ページの難易度と提案手法の Web ページの 難易度との順位相関を評価としており，中程度の相関が 得られているか難易度を推定できるまでには至っていな い。

[Nakatani 09] は文書中の専門用語の出現頻度と, 文 書の読みやすさの指標であるリーダビリティ[Sato 08] か ら，一般的なユーザーにとっての理解の容易さを文書ご とに測定し，測定結果を理解容易度としてWebページに 与えている、リーダビリティの指標は小学生 (1-6) , 中学 生 (7-9)，高校生 (10-12)，高校生より高いレベル(13)の 13 段階に区分されている . [Nakatani 09] を本に適用する ためには, 専門用語の頻度に加え, 難しさも考慮する必 要がある.なぜならば学術本には専門用語がつきもので
あり,どの本にも同じぐらい出現すると考えられるから である.また，Webページは不特定多数の人が書いてい るのに対し，本は推敲や校正が行われているため, リー ダビリティは高くなると予想できる.すなわちこの手法 では本の難易度を推定することは難しいと思われる．

[中條 04] は英語テキストおよび日本語テキストに難 易度を付けている．難易度の指標として英語テキストは 1) 英語リーダビリティ公式によるリーダビリティ・スコ ア，2）日本の中学・高等学校英語教科書に出現しない語 の割合を用いている．また，日本語テキスト部分につい ては，1) 日本語能力試験の語彙 1,2 級の割合，2) 漢字含 有率, というテキストの内容理解に直接影響する要因を 測る指標を用いている. [中條 04] は英語・国語のような 一般向けの本には適用できるが尃門用語の入った専門書 などには適用できない .

\section{$2 \cdot 3$ 読者ネットワークを用いた学術本の難易度推定手法}

[三好 10] は学術本を主眼として本の難易度を推定して いる. 以下の 3 つの仮説を基に誰がどの本を読んだかと いう関係から成る読者ネットワークを用いて難易度の推 定を試みている.(1)ある分野の本を多く読んでいる人は， 弚の分野について詳しい. (2) 詳しい人に読まれている本 ほど難しく，詳しくない人に読まれている本ほど易しい， （3）難しい本を読んでいる人は詳しく，易しい本を読んで いる人は詳しくない. [三好 10] は一般書·専門書にも対 応しており，本論文ではこの手法を従来手法とし，比較 を行う. 従来手法のアルゴリズムは以下の通りとなって いる . 従来手法は上記の 3 つの仮説に基づき，Web ペー ジの重要度の指標となる HITS[M.Kleinberg 98] アルゴリ ズム内の authority と hub の概念を用いている. 図 1 に示

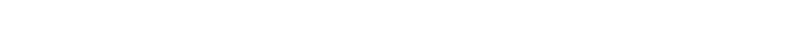
た 2 部グラフを扱う.エッジは読者と読者が読んだ本と 結ふ読者関係を表し，無向グラフである．この手法では， 「本」ノードは尺度として難易度をもち、読者」ノードは 習熟度をもつ、難易度は HITS における authority に相当 し，習熟度は hub に相当する. 読者ネットワークが与え られた時, HITS と同樣に, 反復計算により読者 $u$ の習 熟度 $a_{u}$, 本 $i$ の難易度 $d_{i}$ を次式で求めることができる.

$$
\begin{array}{r}
a_{u}=\sum_{i \in I_{u}}\left(\dot{d}_{i}-p_{a}\right) \\
d_{i}=\sum_{u \in U_{i}}\left(\min \left(\dot{a}_{u}, p_{d}\right)-0.5\right)
\end{array}
$$

$\dot{a_{u}}$ は $a_{u}$ を正規化したもの， $\dot{d}_{i}$ は $d_{i}$ を正規化したもの， $I_{u}$ は読者 $u$ か読んだ本の集合， $U_{i}$ は本 $i$ を読んだ読者の 集合である . 正規化の方法は偏差值を 100 で割っている . $p_{a}, p_{d}$ はパラメータである.初期值として全ての本の難 易度を 0.5 とし, 計算結果が収束するまで式 1,2 を繰り返 す. [三好 10] では読者ネットワークを構築した時点で読 者が末読であるのか, 読み始めたばかりなのか, 一通り 
読んだのかなどといった進度情報を考慮していない，例 えば，未読であればユーザーの習熟度は皆無であり，一 通り読んでいれば習熟度は上がっている.よって，本の 難易度に誤差が発生すると考えられる。

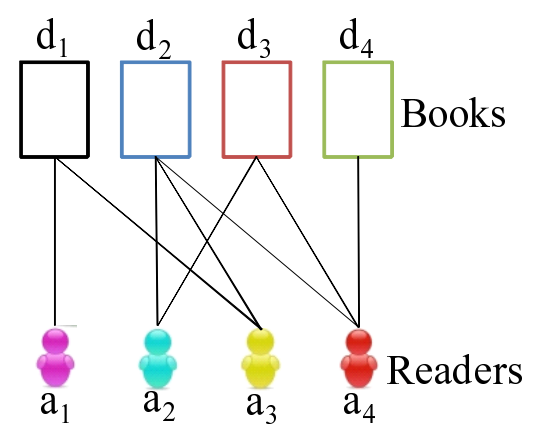

図 1 従来手法の読者ネットワーク例

\section{3. 提 案 手 法}

\section{$3 \cdot 1$ 提案手法の概要}

本論文における難易度とは, 効率良く学習するための 段階的に示した学習過程 (順番) と対応付けた値と定義す る。つまり，難易度が相対的に高いほど後半に学習すべき 本ということになる.このように定義される難易度の妥 当性については $4 \cdot 1$ 節で後述する . 本論文で提案する難 易度推定手法は, [三好 10] とはアプローチが異なり, 自 然言語処理の技術を用いたものとなっている . 具体的に は, Amazon の本のレビューを用いて相対的な本の難易 度を推定する.レビューはユーザーがある物に対する興 味度合いや役に立ったかについて記述されたテキストで ある・レビューデータを用いる利点としては専門的な本 であれば光の本が難しかったのか, 読み易かったのかな どといった評価がされており，難易度推定のためのデー タとして期待できる．また，レビューはユーザーが本を 読んでいることが前提であり，読者の進度の問題はない， 弚こで，レビューの特性について，我々は次のような 2 つの仮説を立てる .

仮説 1 難易度が低い本ほどレビュ一内で「わかりやす い」や「読みやすい」などの評価を受けている

このような評価をしているユーザーが多いほどその本は 難易度が低いと考えられる. 実際にレビュ一内に書き込 まれている評価を図 2 に示す . 本論文では図 2 のような 下線部の形容詞の評価を評価表現と表記する .

仮説 2 (1) 難易度が高い本ほどレビュ一内に光の本が 関連する分野の専門用語がより含まれる傾向にある (2) また含まれる専門用語が難しくなる傾向にある

難易度の高い本は, 難易度の低い本に比べ難しい専門用 語が登場するため理解するのがより難しくなる.ユーザー は光の本の内容についてレビューを書き込むのでレビュー 内に弚のような専門用語が出現すると考えられる. 弚れ に伴い, レビュー内の専門用語の出現頻度は高くなると \begin{tabular}{l}
\hline ·また三色刷で 見やすく图も挿入されていてわかりやすい \\
·光の中で、最も理解しやすかったのがこの本です. \\
·又、初心者に教えるときに補助教材にしながら説明をして \\
もとつつき易くて、いいかもしれない.
\end{tabular}

図 2 レビュー対象が本の評価例

考えられる

提案手法は以上の仮説に基づきレビュー内に出現する 評価表現と専門用語を用いて C 言語に関する本を対象と し，学術本の難易度の推定を試みる。提案手法の流れを 图 3 に示す . 提案手法は統計処理と計算処理の二つに分 かれている . 以下, $3 \cdot 2$ 節〜3.4 節で統計処理について， $3 \cdot 5$ 節〜3.6 節で計算処理について説明する.

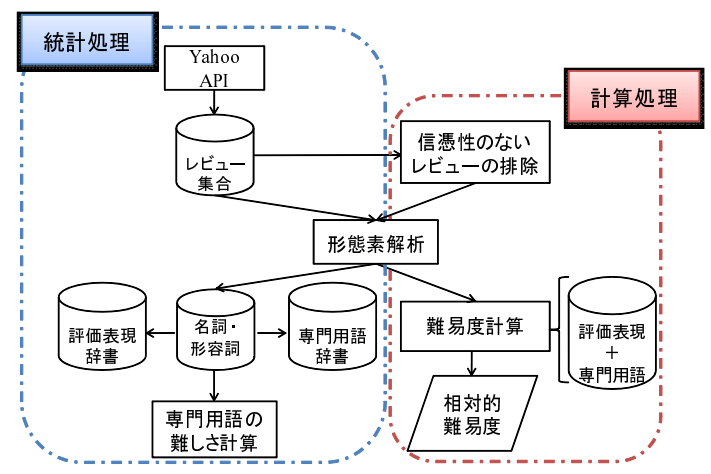

図 3 提案手法の流れ

\section{$3 \cdot 2$ 評価表現辞書の構築}

まず，Yahoo!が提供している Yahoo!API *1 利用し， Amazon からレビューを取得する. 本論文では平成 23 年 3 月 17 日より過去である全てのレビューを用いる. そし て評価表現および専門用語を抽出するために $\mathrm{MeCab}^{* 2}$ を 用いて形態素解析を行う．なお，レビューを形態素解析 するためには，レビューを文単位に分割する必要がある． レビューの分割には文末記号（。.!?）を用いた．光の際， 文末にでてくる括弧の補足情報, 鍵括弧や括弧の中の文 末記号など，本来分割すべきではないところでは経験則 により手動で行った . 次に , 形態素解析によって得られ た品詞情報から「分かりやすい」・読みやすい」といった 形容詞を抜き出し, 評価表現辞書として登録する。評価 表現辞書は表 1 のように 2 つシジャンルを合わせた 5113 文で高頻度で出現した表現を MeCab 辞書に登録する.辞 書中の評価表現の一覧を表 2(a)に示す．

評価表現辞書には「易しさ」を表現する語のみを登録 しているが,「わかりにくい」や「読みにくい」など「難 しさ」を表現する語もレビュー中には出現する．よって， 両方の表現を手掛かりにして難易度を推定していく方法 も考えられる.レビュー中には図 4(a)，(b) の下線部のよ

$* 1$ http://developer.yahoo.co.jp/webapi/search/

$* 2$ http://mecab.sourceforge.net/ 
うに「易しさ」と「難しさ」を表現する形容詞において レビュー対象の本を評価していない語が見られる．また， 图 4(b)の 1 番目の例では「難しい」という表現において 否定語「ない」が付随する語も見られる．これらの語は ノイズと考えられ，文脈を解析しないとノイズを除去す ることは難しい，表 2(a)，(b) は弚れ光れの表現におけ るノイズ発生率を示している.この表から「難しい」表 現のノイズ発生率の方が高く，また出現頻度が低いため， 本論文では「難しさ」を表現する形容詞は扱わないこと とした .

\begin{tabular}{||l||}
\hline \hline ·微分積分に関してはこれよりも分かりやすくて良い本が山 \\
のように存在する。 \\
·今まで私が見た本は、本来難しいことをわかり易くしよう \\
とするがあまり、逆に考え込むと深みにはまるような傾向が \\
ありました。
\end{tabular}

(a)「易しさ」を意味する評価表現

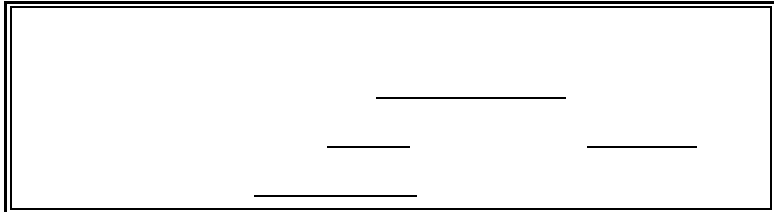

(b)「難しさ」を意味する評価表現

図 4 レビュー対象本の内容を評価していないまたは否定語「ない」 を含む評価表現例

表 1 コーパスの概要

\begin{tabular}{cccc}
\hline 分野 & 冊数 & レビュー数 & レビューの文の数 \\
\hline \hline C 言語 & 59 & 445 & 3247 \\
解析学 & 55 & 237 & 1866 \\
\hline
\end{tabular}

表 2 評価表現のノイズ発生率

(a)「易しい」表現

\begin{tabular}{|c|c|c|c|c|c|}
\hline 評価表現 & 頻度 & ノイズ頻度 & 評価表現 & 頻度 & ノイズ頻度 \\
\hline わかりやすい & 166 & 24 & 難しい & 123 & 66 \\
\hline 分かりやすい & 106 & 13 & わかりにくい & 16 & 6 \\
\hline 読みやすい & 51 & 8 & 分かりにくい & 15 & 7 \\
\hline 分かり易い & 28 & 1 & 読みにくい & 7 & 2 \\
\hline 見やすい & 27 & 3 & 理解しにくい & 5 & 4 \\
\hline 理解しやすい & 23 & 1 & とっつきにくい & 8 & 5 \\
\hline わかり易い & 9 & 1 & 理解しづらい & 2 & 2 \\
\hline 解りやすい & 7 & 0 & 分かりづらい & 4 & 0 \\
\hline とっつきやすい & 6 & 2 & 総頻度 & 182 & 92 \\
\hline 読み易い & 4 & 1 & ノイズ発生率 & & $50.55 \%$ \\
\hline 理解し易い & 3 & 0 & & & \\
\hline 見易い & 3 & 0 & & & \\
\hline とっつき易い & 3 & 0 & & & \\
\hline 総頻度 & 436 & 54 & & & \\
\hline ノイズ発生率 & & $12.39 \%$ & & & \\
\hline
\end{tabular}

\section{$3 \cdot 3$ 専門用語辞書の構築}

本論文では専門用語取得の自動獲得を主眼としていな いので, 手動による専門用語辞書の構築を行う . まず, 専 門用語は単名詞の他に「ポインタ変数」といった複合名詞 から成るものもある . 乥こで, 専門用語抽出には N-gram
モデルを用い , コーパスを C 言語の 3247 文とし , unigram,bi-gram,tri-gram に対して統計をとった . 統計から 得られた単名詞・複合名詞のうち出現頻度が 2 以上でか つ新 ANSIC 言語辞典 [平林 97] に載っている用語を専門 用語として扱うこととした . 結果として 161 語の専門用 語が得られた . 抽出された専門用語の一覧を付録 $\mathrm{A}(()$ 内 の数字は頻度) に示す。

\section{3 .4 共起に基づいた専門用語の難しさ}

本論文では専門用語の出現頻度に加え，難しさを考慮 し難易度を推定する . 難しい専門用語とは, 難しく意味 を捉えにくい用語のことである．また，一般的に専門用 語は出現頻度 (以下 tf 值と書く) が低いほど難しい傾向が ある [中川 03] . しかし「ホポイタ」について詳しく書か れた本のレビュー内には「ポインタ」という語か瀕出す る．光のため，付録 A を見ると専門用語「ポインタ」の tf 值が高くなっている.しかし， C 言語ではポインタは 意味を捉えにくく，難しい用語である．一方，専門用語 $\ulcorner 16$ 進数」は情報学の基礎となる用語であるが , tf 值が 小さく，難しい用語と判断されてしまう．つまり，tf 値 を専門用語の難しさとすると，本来の用語の難しさと乘 離してしまう専門用語が含まれていることになる．本論 文ではこのような語をノイズと呼ぶ .さらにレビュー中 に出現する専門用語の tf 值はかなり差があることもわか る.よって $\mathrm{tf}$ 值を本の難易度に取り入れると「C 言語」 のような tf 值が極端に高い用語に依存してしまうことに なる．つまり，ノイズや頻度の大差が難易度の計算に影 響を及ぼすと考えられる，乥こで, 本論文では単語の共 起性に着目し, 各用語の $\mathrm{tf}$ 值を大小関係を考慮した形で 変化させることを考える.共起性は, 専門用語の関連性 を知る目安として使うことができる [相澤 00, 伊藤 07] . また共起関係にあるものを1つにまとめた時，弚れらは 一つの概念を表しやすい[松尾 02] . 图 5 は 3 冊の本につ いて実際に書き込まれているレビュー各 1 文を載せたも ので， 1 文中に共起している専門用語 (アンダーライン) の例を示している.このように , 共起して出現する専門 用語は同程度に意味が捉えにくいと考えられる.例えば， ある用語がノイズであっても，関連した他の用語と難し さをまとめることにより，本来 $\mathrm{tf}$ 值が持っているノイズ を抑制でき，かつ $\mathrm{tf}$ 值の大差を軽減できる．このように tf 值の傾向を変化させることで, 本の難易度との関連性 がより高くなると考えた . 本論文では, 共起性の尺度と して相互情報量*3を用い, 共起に基づいたクラスタリン グを行うことで $\mathrm{tf}$ 值を変化させる . 共起頻度は文単位で 得るものとし, 以下のアルゴリズムにより共起クラスタ リングおよびクラスタ毎の難易度を付与する .

準備: クラスタ集合を $C$ とし， $|C|=0$ とする. 専門用 語 $w 1, w 2$ の共起頻度を要素とする $161 \times 161$ の共起行

\footnotetext{
*3 相互情報量は以下で表される.

$M I(w 1, w 2)=\frac{N \text { freq }(w 1, w 2)}{\text { freq(w1)freq(w2) }}$
} 


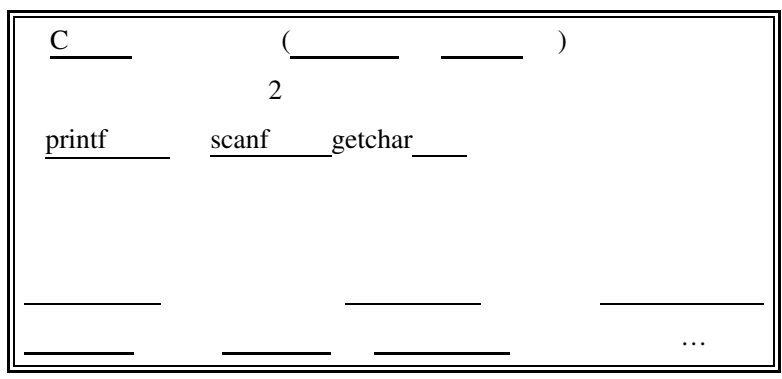

図 5 レビュー中の専門用語共起の例

列を生成し，以下のステップで処理を行う．

ステップ 1 : 専門用語 $w 1$ と $w 2$ のペア*4について, 相 互情報量 $M I(w 1, w 2)>\mathrm{a}$ のとき, 以下の (1) (4)のう ち，条件を満たすものを実行する．

(1) クラスタ集合 $\mathrm{C}$ 要素である全てのクラスタ $C_{i}(i, j: 0$ 〜 $|C|)$ について $, w 1, w 2$ がいずれも $C_{i}$ の要素でなけれ ばまたは $|C|=0$ のとき，新規クラスタ $C_{|C|}$ を作成し， クラスタ集合 $\mathrm{C}$ の要素とする . また $, w 1, w 2$ を $C_{|C|}$ の 要素とする .

(2) $w 1 ， w 2$ が光れクラスタ集合のいずれかののクラ スタ $C_{i}, C_{j}$ に属し,$i \neq j$ であれば， 2 つのクラスタを 統合し 1 つにまとめる.クラスタ番号を整理する .

(3) $w 1$ がクラスタ集合のいずれかのクラスタ $C_{i}$ に属し， $w 2$ がどのクラスタにも属さない場合,$w 2$ を $C_{i}$ の要素 とする .

(4) $w 2$ がクラスタ集合のいずれかのクラスタ $C_{j}$ に属し， $w 1$ がどのクラスタにも属さない場合, $w 1$ を $C_{j}$ の要素 とする .

全ての組み合わせが終わるまでステップ1を繰り返す． ステップ 2 : 各クラスタの難易度をクラスタ内の $\mathrm{tf}$ 值の 中央値とする .

ステップ $\mathbf{3}:$ 専門用語の難しさ $D i f f_{t e c h}(w)$ を式 3 で決 定する。

$$
\operatorname{Diff}_{\text {tech }}(w)=\left\{\begin{array}{cc}
\operatorname{Diff}\left(C_{i}\right) & \text { if } w \in C_{i} \\
t f(w) & \text { otherwise }
\end{array}\right.
$$

ある専門用語 $w$ がずれかのクラスタに属していればク ラスタの難易度を兴の専門用語の難しさとする . 対して ， どのクラスタにも属さない専門用語は元々の $\mathrm{tf}$ 值を用語 の難しさとする . 専門用語の難しさ $D i f f_{\text {tech }}(w)$ は tf 值 に基づくため, 值が小さいほど難しい用語と判断される .

\section{$3 \cdot 5$ 信憑性の低いレビューの排除}

レビューの中には宣伝, 誹謗中傷, 少数意見など低品質 と考えられるものが含まれている．弚のようなレビュー は難易度の計算に影響を及ぼすと考え，レビューの信憑 性を考慮する.ここでは参考度 $f[$ 小倉 08$]$ に基づいて低 品質と考えられるレビューを排除した . 参考度 $f$ は次式

$* 4 \quad w 1$ と $w 2$ の組み合わせは ${ }_{161} C_{2}=12880$ 通り
で定義される．

$$
f=\frac{Y}{N}
$$

$N$ はあるレビューに対する総投票数を表し， $Y$ は「光の レビューに同意する」に投票した数を表す. 式 4 に示す 值が高ければ，多くのユーザーから同意を得ていること を示し，レビューの信頼度が高いということを表してい る. [小倉 08] では信憑性の低いレビューは $f \leq 0.3$ であ るとしている．また，本における参考度のヒストグラム を求めたところ, $f=0.5$ あたりの出現頻度か比較的多く なったという結果が得られた .この結果から $f \leq 0.5$ で あるレビューを除いてしまうと， 1 冊あたりのレビュー 数が激减し，難易度計算に用いるレビューデータが疎に なってしまう．また，参考度が高くても投票数 $N$ が少 ないレビューの信憑性は未知数である.よって本論文で はレビューの信憑性とデータ量を考慮し,$f \geq 0.4$ かつ $N \geq 5$ であるレビュー $R_{i, f}$ を難易度の計算に用いるこ ととした .

\section{$3 \cdot 6$ 難易度の計算}

提案手法では $3 \cdot 2$ 節で挙げた評価表現, 専門用語の出 現頻度，3.4 節で挙げた専門用語の難しさの 3 つの指標 を組み合わせて難易度を計算する . まず本 $i$ の 1 文の形 態素集合 sen を要素とするレビュ一集合を $R_{i, f}$, 評価表 現辞書内の表現集合を $W_{\text {easy }}$ とし，評価表現度 $\operatorname{Easy}(i)$ を次式で定義する．

$$
\begin{array}{r}
\operatorname{Easy}(i)=\frac{1}{\left|R_{i, f}\right|} \sum_{\text {sen } \in R_{i, f}} n_{e}(w, \text { sen }) \\
\text { ただし }, w \in W_{\text {easy }}
\end{array}
$$

$n_{e}(w, s e n)$ は形態素集合 $s e n$ 中に存在する評価表現の個 数を表す.式 5 は評価表現が多く含まれているほど高く なる值であり，仮説 1 によると易しい本ほど大きくなる 指標である

次に本 $i$ の専門度 $\operatorname{Tech}(i)$ を次式で定義する .

$$
\begin{aligned}
& \operatorname{Tech}(i)=\left|R_{i, f}\right| \frac{\sum_{\operatorname{sen} \in R_{i, f}} \sum_{w \in \text { sen }} \operatorname{Diff}_{\text {tech }}(w)}{\left(\sum_{\operatorname{sen} \in R_{i, f}} n_{t}(w, \operatorname{sen})\right)^{2}} \\
& \text { ただし }, w \in W_{\text {tech }} \text { かつ } w \notin w_{\text {parent }}
\end{aligned}
$$

$W_{t e c h}$ は $3 \cdot 3$ 節で構築した専門用語辞書の集合， $w$ は専 門用語辞書に含まれている用語である . $n_{t}(w, s e n)$ は形 態素集合 sen 中に存在する専門用語の個数を表す . 式 6 では本 $i$ のレビュー $R_{i, f}$ 内に含まれる専門用語に対し て $3 \cdot 4$ 節の方法で専門用語の難しさ Diff tech $(w)$ を求め， 弚れを平均したものを本 $i$ のレビュー 1 行あたりに出現 する専門用語の個数で割っている . 仮説 2(2) に基づけば 3.4 節で求めた $D i f f_{\text {tech }}(w)$ は本が難しいほど值は小さ くなる．また，仮説 2(1) によると，レビュー 1 行あた りに出現する専門用語の個数は本が難しいほど大きくな 
る.よって, 両者を割った Tech $(i)$ は難しい本ほど值が 小さくなる . 両者を割るのは専門用語の難しさと出現頻 度のいずれかの指標が異常值を示したときに，他方の指 標で補正を行うためである . 提案手法ではレビュ一中か ら得た名詞から専門用語を抽出するために N-gram モデ ルを用いているため, 次のような問題が発生する．例え ば， bi-gram の語である「ポインタ-変数」が十分な出現 頻度で, 専門用語辞書に登録されている場合, 弚の用語 の一部分からなる「ポインタ」や「変数」も難しさの指 標としてみなしてしまう．これを防ぐために，レビュー

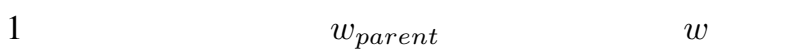
を難易度計算に用いるという制約を設けた [藤村 05] .

最終的に式 5 と式 6 との和を本 $i$ の難易度 Diff $(i)$ と する．

$$
\operatorname{Diff}(i)=1-(\operatorname{Easy}(i)+\text { Const } \times \text { Tech }(i))
$$

式 7 の值が大きいほど難易度が高くなる . Easy $(i)$ ， Tech $(i)$ のどちらかの指標に仮説に反するような異常値 が生じれば，他方の正常値を足すことで炎の異常値を緩 和する方向に働く. また，両者とも仮説に基づく正常値 であれば精度がよくなることが期待できる.なお，Const は正の定数である .

\section{4. 評 価 実 験}

\section{$4 \cdot 1$ 実 験 方 法}

実験 1 : 提案手法の精度を検証するために，被験者に本 を見てもらい，難しい順に並び替えてもらう . ジャンル は C 言語の本を (A)〜(I)の 9 冊 (表 3) とし, 被験者と して C 言語の知識がある高専の情報系 4 年生の学生 17 人を対象にした . 被験者には C 言語の学習カリキュラム に基づき，低学年で実施する内容が多く載っているほど 易しく，高学年で実施する内容が多く書かれているほど 難しいと判断してもらった . 同程度の難易度と判断した 場合には見やすさ ${ }^{5}$ を考慮してもらった . 最も難しいも のは 1 点, 最も易しいものを 9 点とスコア付けしてもら い 17 人分の平均值を正解データとした (正解データ 1 と する) . 学習カリキュラムは教員がある分野を学習しやす いように決めた学習過程である . 教員が決めた学習過程 にしたがって被験者か評価しているので正解データ 1 は 効率の良い学習過程を段階的に示したデータとなる.こ のような難易度の定義により，ユーザーが学習をすると きには教員が立てたカリキュラムにしたがって学習でき， 効率良く学習できると考えられる．なお，信憑性の低い レビューを排除するために参考度を適用し，適用後のレ ビュ一数が 5 末満の本、用語辞典, 解答本, 演習本は難 易度の計算には無理があると考えたため除外した . 従来 手法は [三好 10] を参考にメディアマーカー*6に登録され

*5 評価表現辞書には「見やすい」という表現を入れているため *6 http://mediamarker.net/
ている情報を利用し，読者ネットワークを構築した .

実験 2 : 仮説 2(2) を検証するために情報系の大学生 17 人 に専門用語 161 語に対してアンケートを実施した . アン ケートの内容はある用語を「1. 意味は分からない, 聞い たこともない．2. 聞いたことがあるが説明はできない． 3. 聞いたことがあり，どういう場面で使うかまたは意味 も知っている」の3つに振り分けるものである. 弚れ光 れの選択肢のスコアを 1 点, 2 点, 3 点とし, 17 人分の 平均值を用語の難しさとした (正解データ 2 とする) .

実験 3 : ある本の改訂版が出版されていれば，光れらは 同程度の難易度になるはずである . 乥こで, 本 (C)・(D) の改訂版である『やさしいC 第 3 版 (本 $(\mathrm{J})$ と表記する)』 と『猫でもわかる C 言語プログラミング第 2 版 (本 $(\mathrm{K})$ と表記する)』を 9 冊の本の中に追加し , (J) ・ (K) の難易 度を提案手法で計算し, 計 11 冊の難易度と正解データ との順位相関を求める. 改訂後の正解データは改訂前と 同じ難易度に設定した . 改訂後を混在させた 11 冊の難 易度データを正解データ 3 とする．

表 3 実験に用いる本 11 冊

\begin{tabular}{|c|c|c|c|}
\hline 記号 & 本タイトル & 全レビュー数 & 参考度適用後レビュー数 \\
\hline$\overline{(\mathrm{A})}$ & "プログラミンク言語 ANSI 準拠第2 版 & $4 \quad 43$ & 32 \\
\hline (B) & 新 C 言語入門ビギナー編 & 10 & 5 \\
\hline (C) & やさしいC 第 2 版 & 17 & 14 \\
\hline (D) & 猫でもわかるC 言語プログラミング & 16 & 15 \\
\hline (E) & 新 C 言語入門シニア編 & 10 & 7 \\
\hline (F) & エキスパートCプログラミング & 8 & 6 \\
\hline (G) & 明解 C言語入門編 & 41 & 23 \\
\hline (H) & 新 C 言語入門スーパービギナー編 & 15 & 6 \\
\hline (I) & C 言語ポインタ完全制覇 & 23 & 19 \\
\hline (J) & やさしいC第 3 版 & 13 & 5 \\
\hline (K) & 猫でもわかるC 言語プログラミング第 2 版 & 10 & 7 \\
\hline
\end{tabular}

\section{$4 \cdot 2$ 評 価 方 法}

実験 1 と 3 については, 被験者によってつけられた本 9 冊の難易度の正解データ 1 の大小関係と，提案手法に よってつけられた大小関係との順位相関を評価とする.実 験 2 では正解データ 1 と, 正解データ 2 から計算される 「レビュー中に出現する専門用語 1 語あたりの難しさ」と の順位相関を調べる . 相関の指標にはスピアマンの順位 相関係数 ${ }^{* 7}$ を用いる. 実験 1 における提案手法との比較 対象として (1)[三好 10] の従来手法 (2) 評価表現度 (式 7 の第 1 項のみ) で推定した場合 (3) 評価表現度 $+\mathrm{tf}$ 値のみ を用いた専門度の場合 (4) 専門度 (式 7 の第 2 項のみ) で 推定した場合を用いる．また，共起クラスタリング時の 相互情報量の閾値 a を徐々に変化させたとき, 弚して難 易度の計算に全てのレビューを用いた場合と，参考度を 適用した場合で, 提案手法の精度がどのように変化する のかを調べた . 従来手法のパラメータは従来手法を参考 にし, 弚れ帒れ $p_{a}=0.4, p_{d}=0.8$ とした . 提案手法のパラ メータ Const は 0.001 と設定した。

\footnotetext{
*7 スピアマンの順位相関係数 $r_{s}$ は以下のように表せる $r_{s}=1-\frac{6}{N\left(N^{2}-1\right)} \sum_{i=0}^{N}\left(x_{i}-y_{i}\right)^{2}$
} 
表 4 各手法と正解データ 1 とのスピアマン順位相関係数の比較

\begin{tabular}{ccccccccccc}
\hline 手法 & & MI $>2.0$ & 2.5 & 3.0 & 3.5 & 4.0 & 4.2 & 4.5 & 5.0 & 5.5 \\
\hline \hline (1) 従来手法 & 0.633 & - & - & - & - & - & - & - & - & - \\
(2) 評価表現度 (信憑性考慮) & 0.767 & - & - & - & - & - & - & - & - & - \\
(3) 評価表現度 + 専門度 (tf)(信憑性考慮) & 0.733 & - & - & - & - & - & - & - & - & - \\
(4) 専門度 (信慿性考慮) & - & 0.700 & 0.700 & 0.617 & 0.800 & 0.867 & 0.850 & 0.617 & 0.683 & 0.683 \\
(5) 提案手法 (信憑性考慮) & - & 0.767 & 0.767 & 0.767 & 0.850 & 0.800 & 0.800 & 0.833 & 0.733 & 0.733 \\
(6) 評価表現度 (信憑性考慮せず) & 0.800 & - & - & - & - & - & - & - & - & - \\
(7) 専門度 (信憑性考慮せず) & - & 0.600 & 0.600 & 0.433 & 0.650 & 0.417 & 0.417 & 0.533 & 0.517 & 0.517 \\
(8) 提案手法 (信憑性考慮せず) & - & 0.800 & 0.800 & 0.800 & 0.833 & 0.717 & 0.717 & 0.667 & 0.717 & 0.717 \\
\hline
\end{tabular}

\section{5. 実験結果·考察}

\section{$5 \cdot 1$ 提案手法と他手法の精度比較}

表 4 に実験 1 の結果を示す .ここでは，MI の閾値 a を変化させた場合の順位相関の值を, 各手法と利用した レビューの信憑性毎に示している．すべてのパターンに おいて, 提案手法は従来手法より高い相関係数を得てい る.また，提案手法の第 1 項のみを難易度付与に用いた 場合，第 2 項のみを難易度付与に用いた場合と比較して も提案手法が高い傾向にあることが分かる . スピアマン の順位相関はデータの半数の順序が入れ替わると相関係 数がほぼ 0 となる評価指標であるが [加藤 03], 高い正の 相関が得られたことから本手法は有効な推定手法である と言える .

次に，Spearman の検定表を用いて，実験結果から得ら れた相関係数が有意に0ではない(偶然起こったもので はない)ことを確かめる.帰無仮説 $H_{0}$ を「提案手法と正 解データの相関係数は 0 である」とする. 検定表から提 案手法の全てにおいて $p<0.05^{* 8}$ で帰無仮説を棄却でき 「提案手法と正解データ間には相関性がある」と言える。 また，KS 検定 (片側) により専門度の項だけで推定した 場合の相関係数と提案手法で推定した場合の相関係数と の間に有意水準 5\% で中央値に差があることか認められ た ${ }^{* 9}$.このことから提案手法はより正しく難易度推定が できていると言える .

\section{$5 \cdot 2$ 難易度と評価表現・専門用語の関係}

表 4 から評価表現度は正解データとの相関係数が 0.767 と高いため, 難易度が低い本ほど評価辞書内の表現が多 く，難易度が高い本ほど少ない傾向にあると言える．

表 5 は本の難易度を正解データ 1 に沿って左から高い 順に並び替え，各本の 1 文あたりに出現する専門用語の 頻度を表している.この表から，正解データ 1 との順序 相関係数 0.717 が得られ, 難易度が高い本ほど専門用語 が含まれている傾向にあることが分かる．

以上のことから，評価表現および専門用語の出現頻度 は，本の難易度を推定するための指標として有効である と考えられる。

$* 8 \quad$ 相関関係が誤差である確率が $5 \%$ 末満である

*9 平均値に着目しなかった理由は提案手法における相関係数の 数值に正規性がなかったためである.

\section{$5 \cdot 3$ 共起クラスタリングの効果}

表 4の手法 (3)の精度は提案手法よりも低い結果となつ た . 乥こで, 実験 2 で各本の難易度と，専門用語の難し さ語との相関を取ったところ 0.433 と中程度の相関係数 が得られた .この結果から，難易度が高い本ほど意味を 捉えにくい用語がっっている傾向にあるとは言いにくく， 全ての用語の tf 值のみを用いて難易度の計算をするとさ らにノイズが入る危険性があることが分かった . 図 6 は 相互情報量の閾值 a を変化させたときの各本の専門用語 1 語あたりのの難しさを示している . なお， $a=9.5$ の ときに $|C|=0$ となり， $a \geqq 9.5$ においては共起クラス タリングが行われないことがわかった . 图 6 より，共起 に基づき $\mathrm{tf}$ 值を平滑化させたことで , $\mathrm{tf}$ 值のみを使った よりも MI が 3.5 4.2の閾値によるクラスタリング後の 方が , 式 7 第 2 項の順位相関が上昇している. 弚れに伴 い提案手法の精度も向上している．また，相互情報量の 閾値を小さくしていくにつれ，あらゆる専門用語 $w$ が互 いに共起するようになり，ほとんどの専門用語において $\operatorname{Diff}_{\text {tech }}(w)$ が同值になっていく. 兴の結果，図 6 では $\mathrm{MI}<3.0$ のときにレビュー内の専門用語の難しさ語が各 本ともほぼ等しくなっている .つまり，tf 值を平滑化さ せすぎると専門用語の難しさの情報がなくなり，手法 (2) との順序相関 0.767 と一致する . 対して , MI > 5.0 のよ うに閾值が高すぎると，共起クラスタリングされず，手 法 (3) との順序相関 0.733 と一致していることが分かる. tf 值の傾向を崩さず平滑化する方法として対数を取るこ とも考えられるが, 底を 2 とし式 7 に適用したところ， 正解データ 1 と式 7 第 2 項の順位相関は 0.633 となった . よって, 共起性による値の平滑化がより本の難易度との 関連を持っている。

次に, 共起クラスタリング後で tf 值がどのように変化 したのかを確かめた . tf 值の用語の難しさと MI 適用後 の難しさを，難しさ別に 15 個のクラスタに分け*10，ク ラスタの難しい順に並び替える.ndpm 法 ${ }^{* 11}[$ 横森 04] に より，tf 值と MI 適用後の用語の難しさの大小関係の類 似度を求める。

$$
\operatorname{ndpm}\left(\succ_{t f}, \succ_{M I}\right)=\frac{\text { error }}{{ }_{161} C_{2}}
$$

$* 10$ 共起クラスタリング後の専門用語の難しさは同値である用語 が多いのでクラスタに分けた

*11 用語 $w 1, w 2$ があつたときに $C(w 1) \succ_{t f} C(w 2)$ かつ $C(w 2) \succ_{M I} C(w 1)$ を error とする 
表 5 本の難易度と専門用語の出現頻度との関係

\begin{tabular}{cccccccccc}
\hline 本の種類 & $(\mathrm{F})$ & $(\mathrm{I})$ & $(\mathrm{E})$ & $(\mathrm{A})$ & $(\mathrm{G})$ & $(\mathrm{B})$ & $(\mathrm{D})$ & $(\mathrm{C})$ & $(\mathrm{H})$ \\
\hline \hline 専門用語の個数/レビューの文数 & 1.311 & 1.257 & 0.731 & 1.092 & 0.671 & 0.667 & 0.610 & 0.606 & 0.969 \\
\hline
\end{tabular}

tf 值と相互情報量適用後の専門用語の難しさの距離が変 化しなければ, 専門用語の難しさを崩さない(考慮した) 状態で值を変化させたことになる . 結果は $\mathrm{MI}<3.5$ は $0.265, \mathrm{MI}<4.0$ では $0.237, \mathrm{MI}<4.2$ では 0.235 と約 $75 \%$ 大小関係に変化がなかったため, $\mathrm{tf}$ 值の傾向が崩れてい ないことが分かる。

今回 , 全ての専門用語の難しさを難易度計算の指標と したが, 実験 2 で被験者がつけたスコアが 2 末満の比 較的意味を捉えにくい専門用語のみの総和を調べたとこ ろ，本の難易度の正解データ 1 との相関係数が 0.433 か ら 0.772 となり，高い相関が得られた .このことから専 門用語の難しさを同定し，用語の難しさ top N (N:自然 数) だけを難易度の計算に使えば, 精度が上がると考え られる。

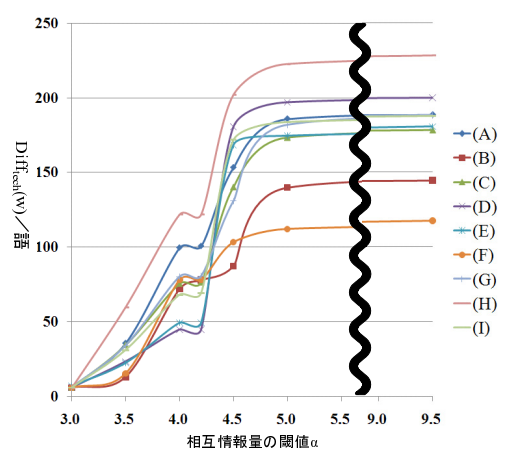

図 6 閾値の変化と専門用語の難しさ/語の関係

\section{4 改訂版との比較}

表 6 は実験 3 における相互情報量の閾値が 3.5 のとき の, 本 $(\mathrm{J}) \cdot(\mathrm{K})$ の改訂前後と正解データ 3 の難易度順位 を示している.また，()内の数值は提案手法によって計算 された難易度 Diff $(i)$ を表している . 提案手法による本 11 冊の難易度と正解データ 3 との順位相関係数は 0.850 から 0.785 に変化した . 低下の原因として表 6 のように 本 $(\mathrm{K})$ の改訂後と正解データの順位差が改訂前との順位 差よりも大きくなったためである．また，正解データ 3 において改訂前後の難易度を同值としているので提案手 法による難易度計算でも難易度が完全に一致しない限り， 順位相関は低下すると考えられる . 本 (J)では Diff $(i)$ が 0.636 と圧倒的に低く，一番易しい本と推定されており， 改訂前後で難易度の開きが生じていることが分かる . こ れは 1 レビューあたりの行数が少ないレビューが多いこ とや評価表現が1文中に複数出現し, Easy $(i)$ の項が大 きくなりすぎたためである .

今回はパラメータ Const の值を経験的に定めたが , 実 験結果において Const を大きくしていく $(T e c h(i)$ の重
表 6 本 $(\mathrm{J}) \cdot(\mathrm{K})$ の改訂前後と正解データの難易度順位

\begin{tabular}{l|ccc} 
& 改訂前 & 改訂後 & 正解データ \\
\hline 本 $(\mathrm{J})$ & $7(0.8560)$ & $11(0.6360)$ & 9 \\
本 $(\mathrm{K})$ & $6(0.8760)$ & $4(0.9203)$ & 7 \\
\hline
\end{tabular}

みを増やす) ことで提案手法は $\operatorname{Easy}(i)$ の異常值に対応

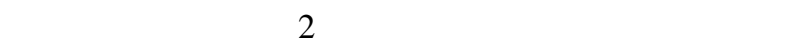
ず，信頼性の高い指標に重みを強くすることで精度の向 上が見込める . 実験結果より Tech $(i)$ は相互情報量の閾 値 a か変化しても順位相関が高い傾向にあり信頼性の高 い指標と考えられるが断定はできない．よって，指標の 信頼性を考慮したパラメータの決定方法は今後の課題と なる. 提案手法では評価表現の個数を数えているが, 評 価表現が含まれている行数を数えれば, 評価表現が複数 個出現する影響を抑えることができる . また , 目次は改 訂前後でも変化しないと予想できるので目次と組み合わ せた難易度推定も考えられる。

\section{$5 \cdot 5$ 信憑性の低いレビューを除いた効果}

表 4 の手法 (5) と手法 (8) を比べると全てのレビューを 難易度計算に用いると提案手法の精度が落ちることが分 かる．また，提案手法の第 2 項である専門度を調べると， 手法 (4) と比べて, 手法 (7) のほうが精度が悪くなって いることも分かる . この原因を明らかにするために，専 門用語の出現頻度と正解データ 1 との順序相関において， 全てのレビューを用いた場合と信憑性が低いレビューを 除いた場合を比べたところ，0.717 から 0.633 とわずか な低下が見られた．また，レビューの信憑性を考慮しな い場合, 共起クラスタリング後の専門用語の難しさ語と 正解データ 1 との相関が, 悪い方向に変化したことも分 かった . 特に，本 $(\mathrm{F})$ ，(H) は信憑性の低いレビューの割 合が多く，専門用語の難しさ/語が正解データ 1 との相関 が悪くなるように変動したため, これら 2 冊のレビュー を調べた . 調査方法として信憑性の低いレビュー(低レ ビューと書く) と光うでないレビュー(高レビューと書く) に分け，正解データ 2 に従って光れぞれのレビュ一内に 出現する専門用語の難しさの平均をとった . 結果は, 本 (F) では高レビューの方が低レビューより専門用語が難し くなり，本 $(\mathrm{H})$ では高レビューの方が低レビューより専 門用語が易しくなった . また，専門用語の難しさを正解 データ 2 の代わりに相互情報量の閾値 $\mathrm{a}>4.2$ での「共 起クラスタリング後の専門用語の難しさ」を適用しても 同樣の結果となった .この理由は以下のように考えられ る. 本 $(\mathrm{H})$ は正解データ 1 によると最も難易度の低い本 である .この本の低レビューには専門用語「機械語」や 「共用体」など正解データ 2 が難しいと判断した用語が 
含まれていた . そのため, 低レビューの方が尃門用語が 難しくなっていると考えられる . 難易度が最も易しい本 にも関わらず, 難しい専門用語が含まれているレビュー はユーザーにとって支持されていなかった .一方，本 $(\mathrm{F})$ は最も難易度の高い本とされている . 高レビュ一内には， 「リンカー」,「プリプロセッサ」など正解データ 2 か難し いと判断した用語が含まれていた，一方，低レビューは $\ulcorner\mathrm{C}$ 言語」や「コード」といった正解データ 2 が易しいと 判断した専門用語しか含まれていなかった .これらのよ うに，低品質なレビュ一内の専門用語の難しさは本の難 易度に反比例する傾向にあり，弚れを除くことにより専 門用語の難しさが正解データ 1 との相関をより持つよう になったと思われる .この問題は 2 冊以外の本にも影響 していると考えられるが, 低レビューの割合が低いこと やレビュー内に含まれる専門用語の個数が多いため, 影 響を抑えることが出来たと考えられる。よって，参考度 適用の効果はレビューが比較的多い本には見られなかっ たが , 低レビューの割合が高く，かつレビューが少ない 本にはあったと言える .

\section{5 . 6 提案手法による 22 冊の本の難易度ランキング}

本論文では 11 冊の本に対して難易度を付与し，考察 を行った . 我々はさらに本の冊数を増やした時にどのよ うなランク付けになるのかを調べた . 表 7 は本の冊数を 22 冊にしたときの難易度のランキングを表している .な お，実験で用いた本 11 冊には記号を付加している．7 位 の『独習 $\mathrm{C}$ 第 4 版』では 8 件のレビューがあり，㫕のう ち信憑性が低いレビューの排除によって 3 件のレビュー しか得られなかった .レビュ一数が極端に少ない場合は 難易度の計算をしても信頼性は低い，提案手法では難易 度計算として使うレビューを参考度が 0.4 以上で投票数 が 5 以上としたが , レビューの新しさは考慮されていな い. 参考度と投票数によって排除されたレビューの中に は「4 人中 4 人」のような参考度は高いか投票数が少ない レビューが見られた .このようなレビューは最近書き込 まれたものが多く，信憑性が高い可能性のあるレビュー とみなすことができる.よって，参考度が高く投票数が 少ないレビューの中で，書き込まれた日付が最近のもの を排除しないことで，この問題を解決できると考えられ る。

本の難易度は「レビュー」や「商品の説明」を参照する だけでもある程度の情報は汲み取れる．本論文では表 7 のように難易度情報をランキングで可視化したという点 で「レビュー」よりもユーザーにとって直感的でわかりや すくなる . Amazon の検索結果では膨大な数のレビュー を保持している本が見られ，光れらのレビューを読み終 えるまでには時間がかかってしまう．また，中には信憑 性の低いレビューが含まれている危険性があり，全ての 情報を鵜吞みにはできない，さらに，商品の説明では絶 対的難易度が記述されているが，ある別の本より難しい
のかといった情報はない . Amazon などでは「おすすめ サービス」や「検索結果一覧」により多数の本をユーザー に提示しているので, ユーザーはどうしても他書と比較 してしまう．よって，本論文で求められた難易度ランキ ングは, 学術本を比較し, 選択を支援する指標として大 変有用であると考える。

表 722 冊の C 言語に関する本の難易度ランキング

\begin{tabular}{|c|c|c|}
\hline 順位 & 本のタイトル & 難易度 \\
\hline 1 & エキスパート C プログラミング $(\mathrm{F})$ & 0.9660 \\
\hline 2 & C 言語プログラミング (Computer Science Textbook) & 0.9597 \\
\hline 3 & C 言語ポインタ完全制羁 (I) & 0.9460 \\
\hline 4 & プログラミング言語 C 第 2 版 ANSI 規格準拠 (A) & 0.9442 \\
\hline 5 & C プログラミング専門課程 & 0.9399 \\
\hline 6 & C 言語 (入門ソフトウェアシリーズ) & 0.9234 \\
\hline 7 & 独習 C 第 4 版 & 0.9230 \\
\hline 8 & やさしいC++まずは「C 言語」からはじめよう!! & 0.9215 \\
\hline 9 & 猫でもわかる C 言語プログラミング第 2 版 (K) & 0.9203 \\
\hline 10 & 独習 C 第 3 版 & 0.9167 \\
\hline 11 & 新・C 言語入門シニア編 (E) & 0.9114 \\
\hline 12 & 10 日間でおばえる $\mathrm{C}$ 言語入門教公 & 0.8770 \\
\hline 13 & 猫でもわかる C 言語プログラミング (D) & 0.8760 \\
\hline 14 & これならわかる $\mathrm{C}$ 入門の入門 & 0.8710 \\
\hline 15 & 定本明解 C 言語 (第 1 巻) 入門編 & 0.8650 \\
\hline 16 & やさしいC 第 2 版 (C) & 0.8560 \\
\hline 17 & 新版 明解 C 言語入門編 (G) & 0.8380 \\
\hline 18 & 新・C 言語入門ビギナー編 (B) & 0.8260 \\
\hline 19 & 新・C 言語入門スーパービギナー編 $(\mathrm{H})$ & 0.8130 \\
\hline 20 & $\mathrm{C}$ 言語 (1) はじめての C プログラミング & 0.7520 \\
\hline 21 & C の絵本-C 言語か好きになる 9 つの悲 & 0.7410 \\
\hline 22 & やさしいC 第 3 版 (J) & 0.6360 \\
\hline
\end{tabular}

\section{6. おわりに}

本論文では本を検索・推薦する属性値として嗜好情報 だけでなく本の難易度を考慮する必要があると考え，本 の難易度を推定する手法を提案した .レビュー中に出現 する評価表現と専門用語を用いて推定を行い, 実験によ り従来手法よりも高い精度が得られた .レビューは 1 ケ 月，半年， 1 年後て増えていくため，今後は本の難易度 がどのように変化していくかを調べていく予定である．

既存のシステムでは検索結果の並び替えに難易度とい うキーがなかったが , 提案手法によって推定された難易 度にしたがって並び替えることで, 初学者や次の本を探 すユーザーにとって有用であると考えられる .さらに検 索結果だけでなく推薦方法にも違いが生まれる.Amazon のおすすめサービスでは嗜好情報に基づき，関連のある 本を推薦しているが, 本研究では今閲覧している本の土 a の難易度である本を推薦できるため，学術本の選択支 援に有用である .

また，難易度を数值化することで，難易度の高い本を 読んでいる人は知識量があるなど，ユーザーの知識量推 定が可能になる．すると知識量を属性值とした協調フィ 
ルタリングを行うことで知識量の類似したユーザーが理 解できた，もしくは少し難しいと評価した本を推薦する ことができる．また, 知識量が豊富であるユーザーが分 かることにより，光のユーザーにアドバイスをもらうと いつた学習支援につながることも期待できる．本論文では ジャンルを C 言語に絞つたが , 他分野の学術本のレビュー にも評価表現・専門用語が含まれる．また，同じように tf 值に大差があると思われるため, 他ジャンルの学術本 にも有効であると考えられる．

\section{$\diamond$ 付 録 $\diamond$}

\section{A. 専門用語 161 語一覧}

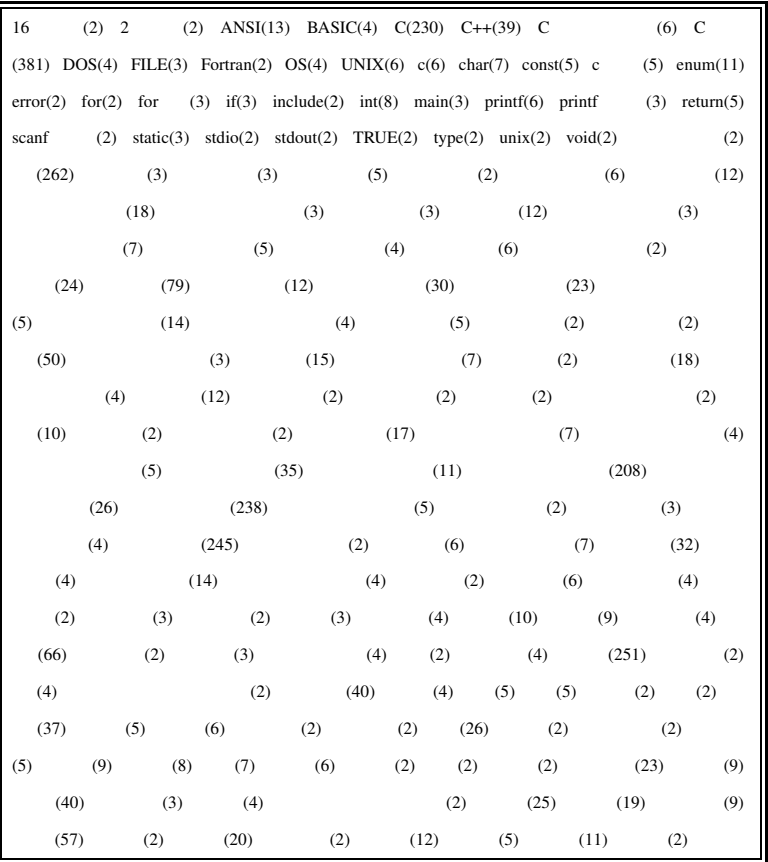

\section{$\diamond$ 参 考 文 献 $\diamond$}

[M.Kleinberg 98] M.Kleinberg, J.: Authoriative Sources in a Hyperlinked Environment, Proceedings of the ACM-SLAM symposium on Discrete Algorithms (1998)

[Nakatani 09] Nakatani, M., Jatowt, A., and Tanaka, K.: Easiest-First Search:Towards comprehension-based Web Search, In Proceedings of the 18th ACM Conference on Information and Knowledge Management(CIKM 2009), pp. 2057-2060 (2009)

[Nishihara 05] Nishihara, Y., Sunayama, W., and Yachida, M.: Information Acquiring Support System based on KeyWords' Continutiy and Informational Difficulty, in Proc. of International Conference on Human-Computer Interaction(HCI2005), Las Vegas (2005)

[Sato 08] Sato, S., Matsuyoshi, S., and Kondo, Y.: Automatic assessment of japanese text readability based on a textbook corpus, In 6 th LREC (2008)

[伊藤 07] 伊藤 雅弘, 中山 浩太郎, 原 隆浩, 西尾 章治郎: Wikipedia のリンク共起性解析によるシソーラス辞書構築, 情報処理学会論 文誌.データベース, Vol. 48, No. 20, pp. 39-49 (2007)

[横森 04] 横森励士, 梅森文彰, 西秀雄, 山本哲男, 松下誠, 楠本 真 二, 井上 克郎：Java ソフトウェア部品検索システム SPARS-J, 電 子情報通信学会論文誌.D-I 情報・システム, I- 情報処理, Vol. 87, No. 12, pp. 1060-1068 (2004)

[加藤 03] 加藤 千恵子, 石村 貞夫 : 相関係数と回帰直線, 東京図書 (2003)

[三好 10] 三好 康夫, 入野 美弥 : 学術書籍の難易度を読者ネット ワークから推定する試み, 電子情報通信学会技術研究報告. ET, 教
育工学, Vol. 110, No. 67, pp. 19-24 (2010)

[小倉 08] 小倉 達矢, 宍戶開, 今藤紀子山口 実靖, 淺谷 耕一 : レ ビューサイトにおける良質なレビューの特性と关れを考慮した 評判情報の抽出に関する一考察, 第 19 回データ工学ワークショッ プ (DEWS 2008)B8-5 (2008)

[松尾 02] 松尾豊, 石塚満: 語の共起の統計情報に基づくキーワー ド抽出アルゴリズム, 人工知能学会論文誌, Vol. 17, pp. 217-223 (2002)

[杉木 08] 杉木 健二, 松原 茂樹 : 消費者の意見に基づく商品検索, 情報処理学会論文誌, Vol. 49, No. 7, pp. 2598-2603 (2008)

[倉島 07] 倉島 健, 別所 克人, 戶田 浩之, 内山 俊郎, 片岡 良治, 奥 雅博 : 比較評価情報に基づくランキング手法, 日本データベー ス学会論文誌 (DBSJ Letters), Vol. 6, No. 1, pp. 5-8 (2007)

[相澤 00] 相澤彰子, 影浦峡 : 著者キーワード中での共起に基づ く専門用語間の関連度計算法, 電子情報通信学会論文誌. D-I, 情 報・システム, I-情報処理, Vol. 83, No. 11, pp. 1154-1162 (2000)

[中川 03] 中川 裕志, 湯本 紘彰, 森 辰則 : 出現頻度と連接頻度に 基づく専門用語抽出, 自然言語処理 = Journal of natural language processing, Vol. 10, No. 1, pp. 27-45 (2003)

[中谷 08] 中谷知博, 星野准一: 経験的価値の分類に基づくゲー ム推薦システム, 情報処理学会研究報告. $\mathrm{EC}$, エンタテインメン トコンピューティング, Vol. 2008, No. 129, pp. 49-56 (2008)

[中條 04] 中條 清美, 白井 篤義, 内山 将夫 : 日英パラレルコーパ スを構成するテキストの難易度分類に関する研究, 日本大学生産 工学部研究報告.B, 文系 37, pp. 57-68 (2004)

[藤村 05] 藤村 滋, 豊田 正史, 喜連川優 : 文の構造を考慮した評 判抽出手法, 電子情報通信学会第 16 回データ工学ワークショッ プ (DEWS 2005) (2005)

[平林 97] 平林 雅英 : 新 ANSI C 言語辞典, 技術評論社 (1997)

[鈴木 09] 鈴木 健太, 濱川 礼：5N-1 他人のコンテンツ評価を用 いたユーザの嗜好推測に基づくコンテンツ推薦 (推薦, 学生セッ ション, データベースとメディア), 全国大会講演論文集, Vol. 71, No. 1, pp. 575-576 (2009)

〔担当委員 : 平嶋 宗〕

2011 年 8 月 4 日 受理

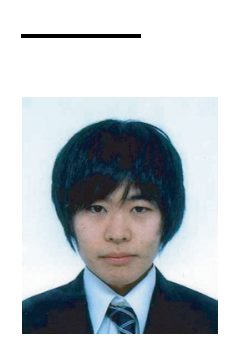

者 紹 介

\section{中山 祐輝}

2010 年金沢大学工学部情報システム工学科卒業 . 2012 年 3 月, 同大学大学院自然科学研究科修士課程修了. 2012 年 4 月より東京工業大学大学院博士課程に在籍. 自然言語処 理, 情報検索・推薦, 評判分析, Web マイニング等に興味 がある. 言語処理学会会員.

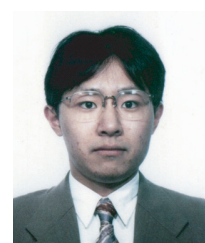

\section{南保 英孝}

1999 年金沢大学大学院自然科学研究科博士課程修了.博士 (工学) . 同年同大学工学部電気・情報工学科助手 . 2002 年 同学部情報システム工学科講師 . 現在, 金沢大学理工学域 電子情報学類講師 .センサ情報処理と关のアプリケーショ ンに関する研究を行っている.電気学会, 電子情報通信学 会, 情報処理学会会員.

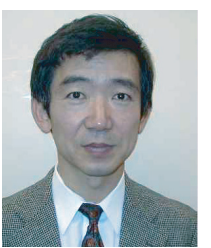

\section{木村 春彦(正会員)}

1979 年東北大学大学院工学研究科博士課程修了。博士 (工 学). 同年, 富士通 (株) 入社. 1980 年金沢女子短期大学 講師. 1984 年 金沢大学経済学部助教授. 現在, 同大学大 学院自然科学研究科教授. この間, 最適コード変換やプロ ダクションシステムの高速化に関する研究に従事、電気学 会, 電子情報通信学会, 情報処理学会各会員 